2013

\title{
Mezzanine Debt and Preferred Equity in Real Estate
}

Andrew R. Berman

New York Law School, andrew.berman@nyls.edu

Follow this and additional works at: https://digitalcommons.nyls.edu/fac_articles_chapters

Part of the Property Law and Real Estate Commons

\section{Recommended Citation}

Berman, Andrew R., "Mezzanine Debt and Preferred Equity in Real Estate" (2013). Articles \& Chapters. 1014.

https://digitalcommons.nyls.edu/fac_articles_chapters/1014

This Article is brought to you for free and open access by the Faculty Scholarship at DigitalCommons@NYLS. It has been accepted for inclusion in Articles \& Chapters by an authorized administrator of DigitalCommons@NYLS. 


\title{
CHAPTER 9
}

\section{Mezzanine Debt and Preferred Equity in Real Estate}

\author{
ANDREW R. BERMAN
}

Professor of Law and Director, Center for Real Estate Studies, New York Law School

\section{INTRODUCTION} In the last 10 years, the commercial real estate market has witnessed drastic changes
in the types and volume of nontraditional financing methods. Before the recession tradition in late 2007, unprecedented growth took place in two types of nonestate borrowal financing: mezzanine debt and preferred equity. During that time, real exceeded the vad hasy access to capital with loan-to-value ratios that sometimes fees from the value of the property, and lenders could earn high interest rates and sion, hom these riskier financings. In the years following the 2008 recession recesdards, and rear, traditional mortgage lenders imposed tighter underwriting stanavailable capital estate owners and developers competed for the limited sources of This provided an a result, the need for alternative funding sources increased. provide liquided an opportunity for a new group of lenders to enter the market to hedge funduidity and additional capital. These nonbank financial institutions and tunities to (many with billions of dollars under management) looked for opporately following provide real estate financing during the volatile time period immeditinue to do so Lehman's collapse and the ensuing financial meltdown and conWith so now.

could obtain manine debt and preferred equity investments, real estate owners funds could much needed capital, and nonbank financial institutions and hedge these riskier and the finance markets and earn high interest rates and fees from these nontradition nontraditional financings. Real estate investors and scholars view major way to fill final financings (i.e., preferred equity and mezzanine debt) as a oWner's equity. the "financing gap" between the senior mortgage debt and the types s equity. This chapter discusses the risks and opportunities of these two tively mantraditional real estate financings. It also examines how investors effecand preferred the inherent risks of, and create opportunities with, mezzanine loans This ched equity investments.

and describes ther is organized as follows. The first part focuses on mezzanine loans With the in the legal and economic structure of mezzanine financings, along second investment opportunities, and the business risks, of mezzanine loans. The part focuses on preferred equity investments and also examines the legal 
and economic structure of these equity investments, along with the investment opportunities and risks of preferred equity.

\section{MEZZANINE LOANS}

In the real estate industry, mezzanine financing is a type of secured loan where the lender's collateral consists of the borrower's equity interests in other entities. With a traditional mortgage loan, the borrower owns the underlying income-producing real estate itself and grants the lender a mortgage lien on the property. However, a mezzanine loan is not directly secured by real estate because the mezzanine borrower does not actually own any income-producing property or other tangible assets. Mezzanine borrowers typically only own equity interests in other subsidiary entities, and these subsidiaries actually own the income-producing real estate. From both an economic and legal perspective, Berman (2007, p. 995) states that the "value of the mezzanine borrower's collateral derives solely from its indirect ownership of the underlying mortgaged property."

Mezzanine borrowers typically pledge as collateral all of their equity interests in the underlying subsidiaries that control, directly or indirectly, the mortgage borrower and the ultimate owner of the underlying real property. Because of this unique legal structure, Fisch, Freidus, and McOwen (2011) explain that mezzanine lenders are structurally superior to equity holders of the borrower, but at the same time they are structurally subordinate to the senior mortgage lender. The mezzanine loan is situated between the more secure senior mortgage loan and the equity investors. The highly leveraged mezzanine loan brings with it both risks and rewards for the parties. The following sections discuss the investment opportunities and risks of mezzanine lending in real estate.

\section{Mezzanine Loans: Investment Opportunities}

The growth of mezzanine loans is to some extent directly linked to the growth of commercial mortgage-backed securities (CMBS). In 2009, national credit rating agencies such as Standard \& Poor's and Moody's required that any mortgage loan included in a CMBS offering prohibit the mortgage borrower from incurring any additional mortgage debt on the income-producing property. Because of this requirement, Rubin (2009) explains that the underwriting guidelines issued by the rating agencies effectively eliminated junior mortgage financing. As a result, the market demanded other types of financing to fill the gap left by the absence of junior mortgages. Lefcoe (2009) explains that mezzanine financing became an attractive form of financing, quickly replacing traditional junior mortgages and growing exponentially. According to Rubock (2007), the amount of mezzanine loans included in commercial real estate (CRE) collateralized debt obligations loans included in commercial real estate (CRE) collateralized debt obligation
(CDO), for example, increased from just a few million dollars to over $\$ 3$ billion
annually.

Mezzanine loans are also popular with real estate owners because many $\mathrm{met}^{\mathrm{T}}$ zanine lenders offer accrual features that defer portions of the interest payments until the mezzanine loan reaches maturity (balloon payment). The unique structure of this loan reduces the burden on current cash flow and consequently has a positive effect on the borrower's debt coverage ratios. Furthermore, senior mortgage 
lenders frequently permit borrowers to obtain mezzanine loans because the loan proceeds often provide the required capital for property improvements and renovations, and these renovations increase the market value of the mortgage lender's collateral. Consequently, real estate owners and developers often seek mezzanine loans to replace traditional junior mortgages and to provide the required capital to close the financing gap between the senior mortgage debt and common equity.

\section{Leverage}

Recently, senior mortgage lenders have adopted conservative lending practices, leaving borrowers with lower loan-to-value (LTV) ratios. Fass, Shaff, and Zief (2011) maintain that as a result of the Dodd-Frank Act of 2010 and the financial regulations that have since been adopted, lending practices now also require higher debt coverage ratios (DCR). The DCR represents a property's net operating income divided by the annual debt service. Because owners are reluctant to inject additional equity into projects, Saft (2011a) contends that mezzanine loans provide these owners with capital to increase their LTV ratios without further encumbering the property with an additional mortgage. Saft also states that although a mezzanine lender is technically a secured creditor of the borrowing entity, credit agencies and senior mortgage holders generally treat mezzanine loans as a form of equity rather than debt, thereby permitting borrowers to increase their financial leverage.

Arnold (2011a) provides that mezzanine loans require higher yields than traditional junior mortgages because the collateral is a "weaker" form of security. For example, Arnold (2011b) asserts that the rapid growth of mezzanine loans in commercial real estate finance has caused lenders to assume more risk in exchange for higher returns. As Duell (2012) observes, mezzanine loan transactions frequently have internal rates of return (IRR) in excess of 20 percent. Dehncke-McGill (2012) prop that mezzanine lenders' target rates of return fluctuate with the quality of the property and the stability of their cash flows. In determining the necessary IRR for mezzanine loan transactions, lenders consider the property location, rating, and ingth of tenant leases, rental income, and the amount of equity at risk.

\section{Maturity of Existing Debt}

ods to past, mezzanine loans successfully provided real estate investors with methor negationanize their capital structure without "watering down" their equity 2006 were bely affecting the senior debt. Duell (2012) states that "[b]oth 2005 and year term big years for conduit lending, and most of those loans had seven to 10\$2.8 trillions." Lee (2011) provides empirical evidence showing that approximately and 2020, with commercial real estate mortgages will be maturing between 2012 a large vith nearly $\$ 1.8$ trillion in debt maturing between 2012 and 2015. With $\mathrm{fe}_{\mathrm{W}}$ ye volume of original senior mortgage debt set to mature within the next gations and property owners need financing sources to refinance their debt oblinity for and fund the gap between debt and equity. Analysts foresee an opportuthese loans.

In the next several years, many opportunities will be available for mezzanine
lenders and borrowers. In describing a recent transaction, Commercial Mortgage 
Alert (2012) illustrates some of the benefits of combining mezzanine loans and preferred equity investments along with traditional senior secured mortgages:

The 1,013-room property, called Parc 55 Wyndham, has $\$ 211.5$ million of outstanding debt that matured yesterday. The Rockpoint team is trying to pay it off by lining up a $\$ 90$ million senior mortgage, $\$ 60$ million of mezzanine debt and $\$ 50$ million of preferred equity. It would also kick in about $\$ 10$ million of fresh equity itself.... As Rockpoint scrambles to arrange fresh financing, high-yield investors are jockeying to buy the existing junior mezzanine debt on the hotel, in order to position themselves to take a run at the property if the refinancing fails. Market pros value the hotel at \$210 million to \$220 million, meaning that the Rockpoint team has little or no equity remaining in the property.

As this example illustrates, the mezzanine borrower can use the loan proceeds to meet certain financial and legal obligations under the existing senior mortgage and to limit the amount of cash equity at stake. Furthermore, the mezzanine lender earns high interest rates while at the same time holding collateral. However, the collateral is actually the mezzanine borrower's equity interests in the underlying entity that indirectly owns the income producing property.

\section{Shifting the Risk through Securitization}

Berman (2005) states that the growth in mortgage securitizations led to the creation of new real estate financing options, such as mezzanine loans and preferred equity. Similarly, Hughes (2011) asserts that the rise in mezzanine loans has been a function of the growth in securitization itself. Lenders use securitized mezzanine loans to raise money through the capital markets in order to fund additional loans to borrowers. Although mezzanine lenders typically experience the first dollar loss if a borrower defaults, mezzanine lenders protect their credit position by shifting the risk to secondary market investors through securitization. Because securitized mortgage facilities prohibit borrowers from acquiring junior mortgages, the structure of mezzanine loans provides borrowers with extra capital without negatively affecting the credit rating of the senior mortgage.

Furthermore, Rubock (2007, p. 1) states that, "[b]ecause of the CRE CDO alternative, mezzanine loans now have a natural capital market, and Moody's rates them in their own right, not viewing them merely as an impediment to higher rating on the senior secured debt." Thus, by packaging mezzanine loans in diverse securitization pools, lenders can shift the risks of real estate projects to investors in the secondary market and raise funds to finance additional real estate projects.

\section{UCC Article 9 and Title Insurance}

As Berman (2007) discusses, mezzanine lenders often find it difficult to enforce their rights and remedies if borrowers default. However, Rubock (2007) notes that mezzanine loans have distinct advantages compared to mortgage financing. For instance, a foreclosure of the collateral in a mezzanine loan under the Uniform Commercial Code (UCC) is considerably quicker than a mortgage foreclosure. Further, with a speedy mezzanine loan foreclosure, highly capitalized mezzanine 
lenders can inject funds into distressed properties more easily and quickly than traditional junior mortgage lenders.

Although mezzanine loan foreclosures are relatively quick, lenders still face many risks because of the unique nature of mezzanine loan collateral. Because the mezzanine lender's collateral (i.e., the equity interest in the mortgage borrower) is technically considered personal property, the UCC governs the foreclosure process rather than traditional mortgage law. As a result, Fisch and Simkin (2008) explain that the mezzanine lender's legal interests in the equity collateral need to be properly "perfected" under applicable UCC law.

\section{UCC Article 9}

Prendergast (2011) confirms that since mezzanine lender's collateral is considered personal property under state law, Articles 8 and/or 9 of the UCC applies depending on certain circumstances. Berman (2007) states that mezzanine lenders need to ensure "attachment" and "perfection" of the security interest in the lender's collateral in order to protect the lender's right to foreclose upon a default. With proper legal drafting, a mezzanine lender can easily structure the transaction so that Article 8 of the UCC governs these issues, and the lender can physically take possession and control of the "stock" certificate evidencing the equity serving as collateral. In the alternative, the lender's collateral may be classified as a "general tangible" under Article 9. Under this provision of the UCC, the secured lender perfects its security interest in the "general intangible" by filing a UCC-1 financing statement in the state where the debtor and collateral are located. In either case, according to Saft (2011a), once the security interest is created, attached, and perfected, mezzanine lenders' lien priority and collateral interest are generally superior to that third-party lien holders.

If Article 8 of the UCC does not govern the transaction, disputes with other lien holders may arise because the determination of priority is based on the "first to file" the financing statement. Consequently, Berman (2007, p. 1004) asserts that perfechold bossession or control typically "ensures a first priority lien over another lien secured who previously perfected by filing a financing statement even if the later zanine party knew of the filing by the previous secured lender." As a result, mezof the lenders often manage these risks by requiring, as a condition to the issuance phy loan, that the mezzanine borrower opt-in to Article 8 of the UCC and deliver pysical control of the certificates to the mezzanine lender.

\section{Title Insurance}

In what began as an attempt to mitigate the risks associated with perfecting security interests, mezzanine lenders now routinely require borrowers to obtain mezzanine loan title insurance. Mezzanine lenders want to ensure that the quality of other title to the underlying property is free and clear from undisclosed liens and borr defects. Typically, the closing of the mezzanine loan is conditioned upon the gage ber's delivery of a special endorsement to the existing title policy of the mortwith borrower. Consequently, the endorsement provides the mezzanine lender borrow right to receive payments otherwise payable to the underlying mortgage rower.

Mezzanine lenders also frequently obtain "title" protection under UCC Article 9 . With this relatively new title insurance product, mezzanine lenders are 
insured against defects in the attachment, perfection, and priority of the lender's lien in the mezzanine loan collateral. The most important protection that a mezzanine lender receives from this type of title policy, however, is that the title company will pay for all legal fees, costs, and expenses incurred in the defense of the lender's security interest in the collateral. Murray and Scott (2006) assert that these title insurance products help insure the quality of the mezzanine borrower's collateral.

\section{Intercreditor Agreement between the Senior Mortgage Lender and the Mezzanine Lender}

The intercreditor agreement is the most important document governing the relationship between the senior mortgage lender and the subordinate mezzanine lender because it governs the parties' respective rights and liabilities in the event of default under the mortgage or mezzanine loan. Although the senior mortgage lender may seriously affect the value of the mezzanine lender's collateral, the mezzanine lender can defend against some of these risks with various protections contained in an intercreditor agreement. Fawer and Waters (2007) state that mezzanine lenders typically modify the standard intercreditor agreement so that the mezzanine lender has (1) the right to receive notice of mortgage default and the opportunity to cure defaults, (2) the right to foreclose on its collateral, (3) the right to purchase the senior mortgage loan, and (4) approval rights over material modifications of the senior loan.

\section{Right to Receive Default Notices and Cure Defaults}

Mezzanine lenders typically require the senior mortgage lender to send them notices of any material default. After receiving a default notice, a mezzanine lender has only a short period of time to decide whether to remedy the default under the mortgage loan. If the default is not remedied, however, the mezzanine lender might lose the value of its collateral because a mortgage foreclosure would result in the sale of the underlying mortgaged property to the successful bidder at foreclosure. Although the mezzanine borrower would still technically own the equity interests in the underlying entities, these entities will no longer own the mortgaged property.

Under a typical intercreditor agreement, mezzanine lenders often have the same time period as the mortgage borrower to cure any defaults under the senior mortgage. Fileti (2012) contends that the standard form of the intercreditor agreement provides "stand-still obligations" on the senior lender following a default under the senior loan. For mezzanine lenders, these provisions provide a right to cure monetary and nonmonetary defaults before the senior mortgage lender takes any enforcement actions, including mortgage foreclosure. Arnold (2011a, p. 2) contends that, "senior lenders [might] welcome the role of the mezzanine lender, [because mezzanine lenders] have an incentive to cure defaults by the borrower in order to prevent a foreclosure and any resulting loss to the mezzanine lender." A mezzanine lender will generally only exercise its right to cure defaults under the senior mortgage when the underlying property's value is greater than the sum of all the outstanding liens on the property or if they believe they can take control of the property and increase its value. 


\section{Right to Foreclose}

The mezzanine lender's primary remedy is the right to foreclose the mezzanine borrower's pledged equity interests. The ability to exercise this remedy depends largely on how broadly the relevant intercreditor agreement defines the term Qualified Transferee. Fawer and Austin $(2011$, p. 2) argue that the "more broadly the term 'Qualified Transferee' is defined, the more liquid the mezzanine loan and the pledged equity become." At the minimum, therefore, the mezzanine lender needs to be a Qualified Transferee so that if the mezzanine lender is the winning bidder at a foreclosure sale, this lender would be protected against the senior mortgage lender challenging the transfer of equity and related change of control. Furthermore, mezzanine lenders ought to protect against the risk that a successful UCC foreclosure will trigger a "due-on-sale" clause under the senior mortgage (because most mortgages define a "sale" to include a change of control of the mortgage borrower).

\section{Right to Purchase the Senior Loan}

If a default exists and the senior mortgage loan has been accelerated, mezzanine lenders usually have the right to purchase the senior mortgage. Fawer and Austin (2011) contend that mezzanine lenders ought to have the option to purchase the senior mortgage after a default until some outside date after the senior mortgagee commences its mortgage foreclosure. Accordingly, mezzanine lenders typically ensure a "right of first refusal" on the senior mortgage at a price that is equal to the outstanding amount due under the mortgage, but that does not require the mezzanine lender to pay any late fees, default interest, or prepayment penalties under the senior loan.

\section{Mezzanine Lender's Rights and Remedies upon Borrower Default}

When a default occurs under the mezzanine loan but there is no default under the senior mortgage, a mezzanine lender's primary remedy is generally to foreclose on the pledged security interest and take over ownership rights of the underlying property. Although Article 9 of the UCC requires a foreclosure sale to be "commercially reasonable," requiring delivery of notice and standard marketing procedures, Fisch et al. (2011) state that mezzanine lenders can usually complete a UCC foreclosure sale in 60 days or less.

In order to protect their rights after a foreclosure, mezzanine lenders normally restrict the mezzanine borrower's right to cause the mortgage borrower to prepay, modify, refinance, or grant additional collateral to the senior mortgage lender. This restriction helps to protect mezzanine lenders from changes under the senior loan that could inhibit the mezzanine lender's remedies. Similarly, Fileti (2011) recommends that the mezzanine lender should perform extensive due diligence of all material contracts relating to the property and/or the mortgage borrower as another safeguard, because after foreclosure the mezzanine lender, in essence, will own and control the property entity subject to those agreements. 
As a practical matter, Fass et al. (2011) state that when there are defaults under both the senior mortgage and the mezzanine loan, the mezzanine lender's principal options are to either remedy the default under the senior mortgage or to purchase the mortgage loan. Berman (2007, p. 1022) contends that most senior mortgage loans provide for some type of purchase option. Mezzanine lenders also face the risk that foreclosure of the mezzanine loan collateral would trigger the "due on transfer" clause under the senior mortgage. As discussed previously, senior mortgage documents typically restrict transfers of the equity in the mortgage borrower or the transfer of the underlying real property. Thus, mezzanine lenders typically draft provisions protecting against the risk that any changes in control of the borrower will not trigger any "due on transfer" clauses under the senior mortgage.

\section{Protection against Bankruptcy Risks}

Some risk exists that the mezzanine or mortgage borrower might file for or become subject to an involuntary bankruptcy. In these cases, there are substantial risks of substantive consolidation, the imposition of the automatic stay limiting the mezzanine lender's ability to act, and the setting aside of pre-bankruptcy transactions as "fraudulent" transfers. In response to these risks, mezzanine lenders generally require that the mezzanine borrower is a bankruptcy-remote special-purpose entity (SPE). Fisch et al. (2011) contend that in a bankruptcy of the mezzanine borrower, the mezzanine lender would typically be able to obtain relief from the automatic stay and exercise its rights and remedies.

\section{INVESTMENT RISKS OF MEZZANINE LOANS}

As discussed in the previous section, mezzanine loans offer tremendous investment opportunities in today's commercial real estate market. However, if care is not taken, mezzanine lenders might suffer the financial consequences of these risky investments, especially because mezzanine loans do not have many of the typical mortgage protections. Berman (2007) contends that mezzanine lenders often lack protections customary to mortgages. For example, mortgage lenders have the following rights: to appoint a receiver, to protect against waste, and to foreclose the borrower's equity of redemption. In addition, basic property law ensures that a mortgage lien will bind future owners of the mortgaged property.

The investment risks involved with mezzanine loan transactions generally occur at four points in time: (1) prior to the origination of the mezzanine loan when the parties assess leverage, the response of the securitization market, and the relative costs and benefits of the investment ("high-yield" issues); (2) at the point of creation, attachment, and perfection of a security interest in, and the economic evaluation of, the mezzanine loan collateral; (3) when negotiating the intercreditor agreement with the senior mortgage lender; and (4) when the mezzanine borrower defaults and the mezzanine lender needs to enforce its remedies. This section discusses in greater detail these investment risks. 


\section{Leverage, Securitization, and High-Yield Issues}

According to Duell (2012), one of the biggest impediments to a robust mezzanine lending market in 2011 was the high price of mezzanine money. As a result, mezzanine lenders responded to stagnant market conditions by offering accrual/balloon payment options and by lowering their interest rates somewhat. Nevertheless, even lower interest rates have not overcome hesitations to incur further debt obligations.

In the basic mezzanine loan transaction, the mezzanine lender is often subject to the liens of the senior mortgage. Berman (2007, p. 999) asserts that "[s]ince only the bottom-tiered entity (the mortgage borrower) actually owns real property, the mezzanine borrower's entire net worth, cash flow, and value of its collateral is derived solely from its (direct or indirect) equity in the entity that owns the underlying income-producing property." Accordingly, even if a mezzanine lender has a perfected security interest in the mezzanine borrowing entity, a mezzanine lender is still junior to any liens that the mortgage borrower has incurred. Thus, if the cash flows from a real estate project are insufficient to cover the borrowers' debt service, the mezzanine lender will absorb the financial loss before any other mortgage lenders.

Furthermore, Moody's rating agency views securitized mezzanine loans as a "weaker" form of security than the traditional second mortgage. Rubock (2007, p. 7) asserts that "Moody's views [mezzanine loans] as having a lesser negative effect on the senior debt, and therefore logically it must bear a greater portion of the expected losses when the total loan leverage defaults." Consequently, in a situation where the mezzanine loan is structured with multiple tranches, the mezzanine lender at the bottom tranche will be forced to either inject more capital into the distressed project or walk away from a failed investment.

\section{Title and Collateral Risks}

Mezzanine loans also carry special title risks because the mezzanine lender's collateral consists of equity, which is legally classified as personal property, rather than the typical real estate collateral with a mortgage loan. Because the lender's ability to foreclose upon personal property collateral depends on adherence to a different body of law, the mezzanine lender needs to take additional precautions to enforce its remedies and foreclose on its collateral.

As discussed previously, mezzanine lenders often require mezzanine borrowers to "opt-in" to Article 8 under the UCC in order ensure that the collateral becomes a "security" under Article 8 and an "investment property" under Article 9. If mezzanine lenders do not require this further protection, the security interest is merely considered a "general intangible" under UCC Article 9. As a result, the evaluation of mezzanine loan collateral differs somewhat from ordinary real estate collateral in a mortgage loan.

\section{Limitations on Rights and Remedies under the Intercreditor Agreement}

Berman (2007, p. 1018) contends that "mezzanine loans are also typically contractually subordinated to the related senior mortgage loans pursuant to the terms of 
an intercreditor agreement entered into between the senior mortgage lender and the mezzanine lender." The intercreditor agreement severely limits and restricts the ability of the mezzanine lender to foreclose or enforce some of the rights under the mezzanine loan. Steiner and Samton (2011) assert that mortgagees and mezzanine lenders often have disagreements if the "value of the [underlying] property drops to or below the amount of the outstanding first mortgage loan, as a result leaving the mezzanine lender with a de facto unsecured debt to a company that, in all likelihood, has no other assets." Accordingly, frequent conflicts and sometimes litigation occur if the underlying property becomes distressed and insufficient income is available to cover the annual debt service.

\section{Limitations to the Right to Cure}

One of the most important limitations provided in the intercreditor agreement is the provision that the mezzanine lender is required to remedy all defaults under the senior mortgage before initiating a foreclosure action against the mezzanine borrower. In Bank of America, N.A. v. PSW NYC LLC (commonly referred to as the "Stuyvesant Town" case), the New York Supreme Court prohibited the mezzanine lender from foreclosing on the borrower's pledged equity without first curing or repaying the outstanding indebtedness under the senior mortgage. The court's decision was based on its interpretation of the "Foreclosure of Separate Collateral" provision under the intercreditor agreement. The court held in the Stuyvesant Town case, similar to Highland Park CDO I Granter Trust, Series A v. Wells Fargo Bank, $N . A$., that because the senior mortgage had been accelerated, "[the] Intercreditor Agreement bars [junior lender] from recovering on the mezzanine loan until the senior loan is repaid in full."

The Stuyvesant Town case clarifies that a mezzanine lender needs to understand and adhere to all of the express obligations under the intercreditor agreement before it takes any remedial action against the borrower. Furthermore, a mezzanine lender is likely to expend an enormous amount of resources to protect its interest in the event of a default under the senior mortgage. Fawer and Austin (2011, p. 2) claim that " $[\mathrm{m}]$ ezzanine lenders should therefore strive to avoid any limitation on the exercise of their right to foreclose, and to make sure that any such foreclosure should never be an event of default under the terms of the senior loan." Accordingly, mezzanine lenders should negotiate provisions that permit a foreclosure of the mezzanine collateral before being required to cure any defaults under the senior mortgage.

\section{Transfer Restrictions}

Intercreditor agreements also usually require that the mortgage borrower be controlled by (and that the mezzanine or mortgage collateral can only be transferred to) a "Qualified Transferee" (QT). A definition of a QT often includes the mezzanine lender itself and an institutional investor who meets minimum "net worth" or "liquid asset" requirements. Prendergast (2011, p. 20) contends that "[a] breach of this requirement by selling to a purchaser that does not meet the standard will probably result in a default under the senior mortgage debt thereby shifting the bargaining power to the senior lender." The QT restrictions limit the availability of potential purchasers of the mezzanine collateral at a foreclosure sale, thereby making the collateral less liquid and potentially less valuable. 


\title{
Replacement Guaranty
}

In general, most senior mortgage holders will negotiate a provision in the intercreditor agreement requiring the mezzanine lender, in the event of a mezzanine loan foreclosure and subsequent purchase of the mezzanine collateral, to provide a replacement guarantor under the senior loan. The theory behind the replacement guaranty is based on the fact that mortgage borrowers are usually obligated under the senior loan to guaranty the loan, assuming any liabilities for acts that the borrower has committed, such as fraud and misrepresentation. If the mezzanine lender purchases the mezzanine collateral at a UCC sale, and steps in as the owner of the mortgage borrower, parties often disagree whether the mezzanine lender (new mortgage borrower) should be obligated to replace the guarantor under the senior loan. Steiner and Samton (2011) explain the issues that mortgagees face if mezzanine lenders do not replace the guaranty under the senior loan:

\begin{abstract}
The concern and uncertainty that many mortgage lenders are facing is the ability to enforce such guarantees if a mezzanine lender has foreclosed and, therefore, controls the mortgage borrower. The guarantor, who is no longer in control of the borrower, would argue that the clear intention of the non-recourse carve-out guaranty is to hold the individual (or equity owner) that makes decisions on behalf of the borrower liable if such borrower commits a proscribed act. If, however, the guarantor is no longer in control of the mortgage borrower (after a mezzanine foreclosure) when, for example, it files for protection under bankruptcy laws, will a court still hold such guarantor to the obligations of the guaranty?
\end{abstract}

\section{Limitations to Rights and Remedies Upon a Mezzanine Borrower Default}

The mezzanine lender often has difficulty foreclosing on the borrower's equity interests after an event of default. This difficulty arises because of the need to comply strictly with the UCC, including the provision stating that foreclosure sales must be commercially reasonable. Mezzanine lenders are also sometimes restricted by limitations set forth in the intercreditor agreement, as well as certain requirements set by the rating agencies. As a result, mezzanine lenders are often under tremendous time pressure to exercise their remedies before the senior mortgage holder completes a mortgage foreclosure. Berman (2007, p. 1023) asserts that "[o]nce the senior mortgage lender completes its foreclosure, the underlying mortgage borrower will no longer own the income-producing property, and the mezzanine borrower will own equity in an entity with no assets."

Moreover, because the mezzanine lender does not have a direct legal relationship to the land, mezzanine lenders generally do not have any direct rights against the mortgage borrower or its equity owners for monetary defaults. Even in situations where the mezzanine lender can foreclose on the pledged equity interests, it simply steps into the shoes of the equity owners of the underlying mortgage borrower. The mezzanine lender is, therefore, in no better position than the previous mortgage borrower-it is still subject to the existing senior mortgage, other outstanding liens, and real estate taxes. Unlike the senior mortgage, the mezzanine lender has no special right to foreclose on any of these other liens and interests attached to the underlying property. Frequently, the mezzanine lender's only true remedy is to refinance the property subject to any prepayment penalties pursuant to the senior mortgage or to buy out the senior lender at par value. 
Another potential risk that mezzanine lenders face, in the event of a default under the mezzanine loan, is a "cash sweep" under the senior loan. Rubin (2009, p. 42) describes a cash sweep as a provision "that permits the mortgage lender to trap all cash flow from the property to pay its debt, property expenses and fund reserves, leaving little or no money to pay the [mezzanine] lender."

\section{Commercially Reasonable}

If a mezzanine lender seeks to foreclose on its equity collateral, it must comply with many of the provisions of UCC Article 9 and sell the collateral either at a private or public sale. Berman (2007, p. 1016) contends that mezzanine lenders cannot effectively dispose of the collateral at a private sale, "[s]ince there is no established market, no standardized price quotations, and mezzanine loan collateral is extremely complicated." Thus, mezzanine lenders cannot "buy" the collateral itself at a private sale because mezzanine loans are not the type of collateral customarily sold on a recognized market or subject to standardized price quotations.

As a result, mezzanine lenders will typically have to sell the pledged collateral at a public sale. However, even a public sale can result in formidable risks because no established market is available for this type of collateral. Accordingly, mezzanine lenders are often left with no choice other than to "buy" the collateral at the public foreclosure sale.

Under UCC $\S 9-610$, the transferability of collateral at a public sale must be "commercially reasonable." Furthermore, some jurisdictions also require lenders to prove that the public disposition of the mezzanine collateral was "commercially reasonable" in order to claim a deficiency judgment. One risk is that some doubt still exists about the exact meaning of "commercially reasonable" in this context. UCC $\S 9-627$ provides that "a disposition of collateral is 'commercially reasonable' if it is made: in the usual manner on any recognized market; at the price current in any recognized market at the time of the disposition; or otherwise in conformity with reasonable commercial practices among dealers in the type of property that was the subject of the disposition." The risk for mezzanine lenders is that, other than the two statutes cited above, the UCC provides little guidance on what constitutes a commercially reasonable sale.

If the foreclosure sale does not meet the requirements for "commercial reasonableness," then the borrower or guarantor may sue the mezzanine lender or be released from any recourse liability. Consequently, mezzanine lenders ought to ensure that they have complied with these provisions.

\section{Bankruptcy and Workout Risks}

In general, the mortgage lender will take action to forbid the mezzanine lender from becoming a secured creditor of the property owner (mortgage borrower). Berg and Gogliomella (2010) contend that so long as an outstanding senior mortgage loan exists, the mezzanine lender is prohibited from causing or influencing the senior borrower to file for bankruptcy or other insolvency proceedings. Rubin (2009) asserts that if the property owner files for bankruptcy, the mezzanine lender typically would not hold a claim to the property owner's assets and would not have voting rights regarding reorganization plans.

In effect, should a plan for reorganization require a transfer of the property from the property owner, the mezzanine lender could be left owning equity in a 
worthless entity. Berg and Goliomella (2010) conclude that if the mezzanine lender is treated as a creditor in the bankruptcy of the mortgage borrower, the mezzanine lender will be prohibited from taking any action in the bankruptcy proceeding without the senior lender's consent, and the senior lender will be authorized to exercise its remedial power against junior creditors. Thus, in order to protect its collateral interest in the borrowing entity, the mezzanine lender might need to invest additional capital into the mortgage borrower for a workout or, alternatively, negotiate a purchase of the mortgagee's interests.

\section{PREFERRED EQUITY}

Preferred equity is another type of nontraditional real estate financing used by property owners to obtain additional capital. Unlike mezzanine loans, where a clear creditor/debtor relationship exists, preferred equity transactions are not structured as debt. Rather, in a preferred equity transaction the investor/lender makes a capital contribution in a special-purpose entity (borrower). This entity normally owns the underlying income-producing real property and is also the mortgage borrower. Fisch et al. (2011) assert that due to restrictions set forth in standard senior mortgages, preferred equity transactions are most often made to borrowing entities that indirectly own the underlying property (instead of the mortgage borrower entity itself).

In exchange for its capital contribution, the investor becomes an equity owner in the mortgage borrower with special "preferred" rights. As Berman (2005) notes, these rights often include: (1) the right to receive a special (or preferred) rate of return on its capital investment and (2) the right to an accelerated repayment of its initial capital contribution. In effect, the preferred rate of return reflects the interest component of a conventional loan, and the accelerated repayment of the investor's capital is analytically similar to the repayment of outstanding principal in a loan.

As structured, preferred equity investors ("preferred members") are structurally subordinate to all of the borrower's creditors (secured and unsecured) but are senior to common equity owners ("common members"). Fisch et al. (2011, p. 1) claim that the biggest difference between the structure of mezzanine loans and preferred equity investments is that:

[I]n general, investments intended to have a simple structure with current payments of interest and a fixed maturity date (with or without extension options) are usually structured as mezzanine loans, while investments with more complicated features, such as a cash distribution "waterfall" that allows the owner/developer to receive some cash flow distributions while the junior capital is still outstanding, or the capital provider sharing in the "upside" on top of its promised return, lend themselves more readily to a preferred equity structure.

Further, preferred members do not have any foreclosure rights, and typically the borrower or borrowing entity does not pledge its equity interests or other assets as collateral. Instead, preferred members have superior contractual rights (compared to the common equity investors) with respect to cash distributions or dividend payments. Preferred members also have specific contract remedies set forth 
in the organizational documents of the entity in the event of a financial delinquency or a "Change of Control Event," which is discussed in the next section.

Preferred equity investments are commonly made when senior mortgage lenders prohibit mortgage borrowers from incurring any further debt. Arnold (2011c) asserts that preferred equity investments are also used when "a property is generating insufficient cash flow to service a junior or mezzanine loan." Although investing in distressed property carries high risks, the structure of preferred equity transactions allows for capital to be injected into these properties without incurring additional debt obligations. Saft (2011b) contends that because preferred equity investors acquire direct equity ownership with the property, they can better protect their capital investment and perhaps obtain higher rates of return if a project is successful. The next section discusses the opportunities and risks of preferred equity investments in real estate.

\section{Preferred Equity Opportunities}

As discussed previously, a preferred equity investor usually makes a capital contribution in the underlying mortgage borrower or a newly formed borrowing entity that indirectly owns the underlying income-producing property. Saft (2011b, p. 1) states that preferred equity transactions have "typically [been] structured as joint venture transactions between the property owner and a capital provider, who enter into an agreement with each other to form ... a limited liability company." In return for its investment, a preferred equity investor receives preferred equity interests with a preferred return, while the other equity investors receive common equity interests with no preferred return.

Preferred members also normally receive any cash distributions or dividend payments before any common equity members. Arnold (2011c) asserts that the right to receive a preferred distribution - at times as much as 18 percent-on the invested equity amount is a key aspect of preferred equity transactions. Although preferred members (as equity) take subordinate positions to all secured and unsecured creditors of the mortgage borrower, preferred members are able to collect high rates of returns, especially when the underlying property is profitable. Furthermore, if the property is underperforming, the preferred member might have the right to take over control of the mortgaged property, or the right to remove voting and control privileges from the common member.

\section{Right to Receive Regular Dividend Payments}

Arnold (2011c) states that real estate investors who are seeking higher rates of return and who are not overly concerned with exit strategies can structure their senior equity position as a "preferred equity member." Although preferred equity transactions can be structured in a variety of ways, a preferred member will usually receive, in exchange for its capital contribution, a preferred rate of return on its investment and an accelerated repayment of its capital. Accordingly, a preferred member normally receives cash payments before any common equity member (property owner). Thus, a preferred member generally receives the repayment of its initial investment before any other equity members and also receives a preferred rate of return. Moreover, if a real estate project is profitable, a preferred member 
may also receive a percentage of the excess cash flow, thereby sharing in any upside appreciation.

In general, the organizational documents provide the preferred rate of return, which is expressed as an annual rate and accrues from the time of the preferred member's initial capital contribution. A common method of cash flow distribution is the "waterfall" method. The waterfall method generally provides the common and preferred members with a distribution structure for any available cash flow after all debt obligations and operating expenses have been paid. According to Spyksma (2011), a typical preferred equity waterfall distributes available cash flow as follows:

- First, to the preferred member in satisfaction of the preferred return on the preferred member's equity investment.

- Second, to the preferred member in an amount sufficient to return the preferred member's initial equity investment (capital contribution).

- Third, to the common member in an amount sufficient to return the common member's capital contributions.

- Finally, the balance of any available cash will be distributed between the preferred member and the common member according to a predetermined percentage. This relatively straightforward waterfall distribution illustrates that the pre-
ferred member receives both a preferred rate of return (the interest component) and a preferred return on its capital investment (the principal component), even before any excess cash flow is distributed to the common equity member. Accordingly, the preferred member has tremendous leverage because it will either receive the preferred rate of return when a project is successful or take over full control of the property if the common equity member fails to pay the preferred return or if preferrect is otherwise failing. In the final step of the above waterfall structure, the preferred member can negotiate the right to share profits or residual interests after the preferred equity "borrower" makes all of its mandatory payments to investors.

Redemption Rights

The organizational documents of these entities normally provide the preferred ferred investor with the right of redemption of its entire capital contribution, prematurity return, and additional cash flow by an agreed-upon date (similar to the operation date of a loan). If the common members, who manage the day-to-day terminens, fail to fully redeem the preferred member's interests by this predeEvent" date, the organizational documents declare that a "Change of Control Althoug occurred (similar to an event of default in a typical loan transaction). mandagh common members might have an opportunity to extend the set date for mandatory redemption, a "Change of Control Event" typically gives the preferred propert full day-to-day control of the mortgage borrower and the underlying bers " sell or may [even] have certain 'springing' control rights that give it authority to ing or refinance the underlying real estate asset or exercise full rights of a managin partner if its position is not redeemed on the anticipated redemption date." 
Moreover, if the common members want to redeem the preferred members' interests in advance of the redemption date, the preferred members usually receive some additional compensation (similar to a prepayment premium in a loan). The amount of this additional fee is often based on whether (and when) the preferred return or initial investment has been (or will be) paid back. Thus, by including a redemption provision in the organizational documents of the relevant entity, preferred members can obtain automatic, self-exercising remedies.

\section{Right to Control and Manage}

In general, preferred members do not have a day-to-day managerial role and only have the right to approve major decisions of the entity. For instance, Fileti (2011, p. 1297) asserts that preferred members retain the following approval rights:

[The right] to consent to any additional capital contributions or admission of additional equity holders; to consent to any filing for bankruptcy or appointment of a receiver; and to consent to major decision such as additional debt; major contracts; affiliate transactions; mortgage loan prepayments or amendments; refinancing; property management arrangements; and modifications to organizational documents.

However, in the event of a failed payment of preferred return, or if the common equity member breaches any provisions of the operating agreement, the preferred member can acquire full or substantial control of the entity. Because a preferred member's financing is structured as an equity investment rather than secured debt, preferred members lack foreclosure rights, but can gain day-to-day control through enforcing its remedies after a "Change of Control Event." Accordingly, Saft (2011b, p. 1) reasons that "[i]f the management of the LLC [borrowing entity] fails to pay the preferred member the promised return, the old management (common members) is ousted and the common members lose their voting rights, dividends, and right to the distribution of any profit."

Furthermore, in some situations a preferred member can force a sale of the property or can purchase the common members' stake to become the sole owner of the underlying property, subject to any outstanding mortgages or other debt obligations. Thus, similar to mezzanine lenders, once the preferred member takes control of the mortgage borrower, the preferred member will have effective control to manage the day-to-day operations of the mortgage borrower and owner of the underlying income-producing property.

\section{Transfer Rights and Bankruptcy}

Senior mortgages often contain due on sale clauses triggered by change of control or transfers of majority interests in the mortgage borrower. However, Saft (2011b, p. 1) states that this is usually not an issue because "many mortgages permit borrowers to make limited transfers of ownership interests in the property owner without the existing lender's consent, usually so long as certain individuals or entities retain either a minimum level of ownership and/or managerial control over the asset." In order to comply with the senior mortgage and still enforce its preferred rights under the organizational documents, preferred members should allow the 
common members to retain a minimum level of equity ownership or obtain confirmation from the senior lender that the preferred member is a "Qualified Transferee" for the same reasons as discussed above. If these steps are taken, the preferred member will not have to obtain the approval from the senior lender in order to enforce its remedies after a "Change of Control Event" occurs. Further, if the borrowing entity files for bankruptcy, preferred members typically want to be characterized as preferred equity holders rather than as secured debt because they do not want to be subject to the automatic stay or other constraints imposed under bankruptcy law.

\section{PREFERRED EQUITY RISKS}

As discussed in the previous section, because of their unique structure preferred equity investments offer the preferred member many benefits. Nevertheless, this unique structure also presents certain risks. This section discusses in greater detail some of the common risks with preferred equity investments.

\section{Limitations as a Preferred Equity Member}

As discussed in the previous section, preferred members do not normally receive any special collateral. Rather, they have to rely on only the specific contractual provisions contained in the organizational documents between the common member(s) and preferred member(s). Although preferred members have contract rights and remedies, Fisch et al. (2011) warn that the preferred member's ability to enforce these rights and remedies can be quite complex, slow, and uncertain. For instance, throug (2011, p. 1297) states that "a [preferred member] may need to enforce its rights downs; contractual and partnership-type remedies that may involve squeezepartner buy-sell provisions; conversion from non-managing member (or limited requirements to managing member (or general partner) status; fiduciary principles; ing whether a contract provision dissolution; and other complications." Even determincan result in time-consuming and costly linge in Control Event" has been breached equity investors have preferred equity have no rights to collateral or any security interest to foreclose, lenders.

\section{Limitations on the Right to Receive Cash Distributions}

In return for its investment, a preferred member obtains preferred shares of equity and a preferred rate of return. The preferred member acquires a senior position to paid). common member to any cash distributions (only after the debt service has been costly to the (2008) contends that preferred equity investments are particularly as high as 20 percent. Although preferred members have a right to receive regular al. (2011) distributions in respect to its senior position to the common member, Fass et of the borrower's Accordingly, given these structural drawbacks, a preferred equity member is likely 
to receive its preferred rate of return and repayment of its original investment only if the underlying real estate project meets its initial projections and generates sufficient cash flow after paying off outstanding debt obligations.

\section{Limitations under the Senior Loan}

As discussed in the previous section, many senior mortgages prohibit a change in the control of the mortgage borrower and/or a transfer of more than 50 percent of the equity therein. Spyksma (2011.p. 110) asserts that mortgage lenders, especially if the mortgage loan is destined for a securitization, want to enforce strictly these approval rights because the mortgage lender is rightly concerned with the financial wherewithal and the "operational capacity and experience" of the new equity holders. The mortgage lender usually includes restrictive covenants and default provisions limiting the ability for a preferred member to take over control of the mortgage borrower after a "Change of Control Event" occurs. If a preferred member obtains control of the mortgage borrower as a result of a "Change in Control Event," this is likely to trigger an accelerated default clause under the senior mortgage.

However, Saft (2011b. p. 1) proposes that "[w]hile a preferred equity structure may potentially run afoul of the ownership transfer restrictions often contained in senior mortgage documents, many mortgages permit borrowers to make limited transfers of ownership interests in the property owner without the existing lender's consent, usually so long as certain individuals or entities retain either a minimum level of ownership and/or managerial control over the asset." Furthermore, a preferred member can also obtain confirmation from the mortgage lender in advance that the preferred member is a permitted "Qualified Transferee."

\section{Bankruptcy Risks}

In a bankruptcy proceeding of the borrowing entity, a preferred member will generally be treated as an equity investment. Nevertheless, if a preferred member displays characteristics of a creditor (e.g., requiring the borrower to pledge collateral in return for the investment), a bankruptcy court may recharacterize the preferred equity transaction into a loan and the preferred member as an unsecured creditor. Additionally, if the mortgage borrower files for bankruptcy, the preferred member has the added risk of substantive consolidation. Substantive consolidation is an equitable doctrine that characterizes separate legal entities as a single-debtor entity. Therefore, a court would possibly not only treat preferred equity investment as debt, but a bankruptcy judge might also order substantive consolidation of the "separate" entities, and the automatic stay would restrict a preferred member's ability to enforce its right to control the borrowing entity. Berman (2005, p. 120) concludes that

preferred equity investors are perhaps unrealistically confident that their transaction documents are actually enforceable, that a bankruptcy court would not order the substantive consolidation of borrower's assets with another bankrupt debtor or void certain transfers as a fraudulent preference, and that the lenders and investors can effectively and quickly enforce their rights and remedies under the transaction documents and obtain control of the underlying property. 
Accordingly, although a preferred member may be able to enforce certain control rights, this member also faces the risks of recharacterization, substantive consolidation, and the automatic stay.

\section{SUMMARY AND CONCLUSIONS}

This chapter has discussed two types of nontraditional real estate financings: mezzanine loans and preferred equity investments. Although each of these financing vehicles is structured differently (one as debt and the other as equity), both allow property owners to obtain funds in excess of the typical senior mortgage loan and to limit the amount of its own equity at risk in a real estate project. Given the unique structure of these financings, real estate owners are able to substantially change the capital stack and its cost of funds. With these opportunities come risks for both the real estate owners and lenders/investors.

\section{DISCUSSION QUESTIONS}

1. What is the rationale for choosing mezzanine loans over traditional junior mortgages?

2. Discuss the legal structure of mezzanine loans. Why are mezzanine loans sometimes considered to combine aspects of debt and equity transactions?

3. Discuss why developers and senior lenders like mezzanine loans.

4. In the event that a mezzanine borrower defaults, identify the remedies available to a mezzanine lender. Discuss the risks that the mezzanine lender faces when enforcing its remedies.

5. Discuss the structure of preferred equity investments. How do they differ from mezzanine loans? How can a preferred equity member gain managerial control of the underlying property?

\section{REFERENCES}

Arnold, Alvin. 2011a. "Short-Term and Medium-Term Financing: In General-The Mezzanine Loan." Real Estate Investor's Deskbook, 3rd ed., §5:47. Valhalla, NY: Warren, Gorham \& Lamont.

Arnold, Alvin. 2011b. "Short-Term and Medium-Term Financing: In General-The Mezzanine Loan-The Growth of Mezzanine Loans." Real Estate Investor's Deskbook. 3rd ed., §5:50. Valhalla, NY: Warren, Gorham \& Lamont.

Arnold, Alvin. 2011c. "Short-Term and Medium-Term Financing: In General-Preferred Equity." Real Estate Investor's Deskbook. 3rd ed., § 5:49. Valhalla, NY: Warren, Gorham \& Lamont.

Berg, Mitchell, and Salvatore Gogliomella. 2010. "Rights and Restrictions in Intercreditor Agreements; Real Estate." New York Law Journal, October 20. Available at http://realestateclips.blogspot.com/2010/10/rights-and-restrictions-in.html.

erman, Andrew R. 2005. "Once a Mortgage, Always a Mortgage-The Use (and Misuse) of Mezzanine Loans and Preferred Equity Investments." Stanford Journal of Law, Business,

Berman, Finance 11:1, 76-125.

72.4, Andrew R. 2007. "Risks and Realities of Mezzanine Loans." Missouri Law Review 72:4, 993-1030. 
Commercial Mortgage Alert. 2012. Rockpoint Scrambling to Refinance SF Hotel. February 10. Available at www.cmalert.com/headlines.php?hid $=155890$.

Dehncke-McGill, Melissa. 2012. Private Equity: Who's Ahead. NYC Real Estate Private Equity Players Weigh in on Where They're Raising Capital and What Kinds of Investments They're Eyeing This Year. March 1. Available at http://therealdeal.com/issues_articles/private -equity-whos-ahead.

Duell, Jennifer. 2012. "Mezzanine Lenders Look Forward to a Big Year." National Real Estate Investor. February 2. Available at http://nreionline.com/finance /mezzanine_lenders_big-year_02022012/.

Fass, Peter M., Michael E. Shaff, and Donald B. Zief. 2011. "Commercial Mortgage-Backed Securities and Commercial Debt Obligations." Real Estate Investment Trusts Handbook. $\S 1: 39$.

Fawer and Austin. 2011. "Intercreditor Agreements 2.0: Lessons Learned in the 'Tranches." New York Law Journal, November 21. Available at www.dicksteinshapiro.com/files /Publication/8f66682f-c446-4936-abdd-00a9337fc76e/Presentation/PublicationAttachm ent/84baa7fb-ab1d-4f40-a320-b9a89c0d4ed0/Lessons_Learned_Tranches.pdf.

Fawer, Mark S., and Michael J. Waters. 2007. "Mezzanine Loans and the Intercreditor Agreement: Not Etched in Stone." Real Estate Finance Journal, Spring, 79-85. Available at www.dicksteinshapiro.com/files/Publication/427b6314-e547-40de-9e31-5e0e18a69c7a /Presentation/PublicationAttachment/f0db8de8-3e64-44dd-ab40-aa956023f0a9/ Mezzanine\%20Loans\%20and\%20the\%20Intercreditor\%20Agreement.pdf.

Fileti, Thomas R. 2011. "Subordinate and Mezzanine Real Estate Financing." The American Law Institute ST005 ALI-ABA 1485-1499.

Fileti, Thomas R. 2012. "The 'CMBS FORM' of Intercreditor Agreement-Time for a Fresh Look?” Commercial Real Estate Financing 2012: Getting Back to Business 2, $29-54$.

Fisch, Peter, Harris B. Freidus, and Micah J. B. McOwen. 2011. "Preferred Equity and Mezzanine Loans as Subordinate Financing Tools." New York Law Journal, November 30. Available at www.paulweiss.com/media/109627/nylj_30nov11.pdf.

Fisch, Peter E., and Steven Simkin. 2008. "Foreclosing on a Mezzanine Loan under UCC Article 9." New York Law Journal, May 7. Available at http://ul.firstam.com /assets/DFBEBD5D-3183-4C27-B9D6-9D595A02FE61.pdf.

Hudgins, Matt. 2008. "Catch-22 in Mezzanine Lending." National Real Estate Investor. Available at http://nreionline.com/finance/investors/real_estate_catch_mezzanine_lending/

Hughes, Heather. 2011. "Securitization and Suburbia." Oregon Law Review 90:2, 359412.

Lee, Evelyn. 2011. "Teeing Up Debt." CBRE. Available at http://www.cbreglobalinvestors .com/aboutus/mediacenter/capitalmarketscommentary/Documents/mediacoverage /Teeing\%20Up\%20Debt.pdf.

Lefcoe, George. 2009. Real Estate Transactions, Finance, and Development, 6th ed. New York: LexisNexis.

Murray, John C., and Randall L. Scott. 2006. Title Insurance for Mezzanine Financing Transactions. Available at www.firstam.com/title/resources/reference-information/jackmurray-law-library/title-and-ucc-insurance-for-mezzanine-financing-transactions.html.

Prendergast, James D. 2011. "Real Estate Mezzanine Lending Collateral Foreclosure: Insurance Tailored to the Operation of the U.C.C. Is Not a Luxury-It's a Necessity." Practical Real Estate Lawyer 27:6, 11-31.

Rubin, Paul. 2009. "Strategic Thinking for the Mezzanine Lender." American Bankruptcy Institute Journal. 28:8, 42-43, 88 .

Rubock, Daniel B. 2007. Moody's Investors Service, US CMBS and CRE CDO: Moody's Approach to Rating Commercial Real Estate Mezzanine Loans. March 29. Available at http://dirt.umkc.edu/attachments/MDYMezz\%20Loans.pdf. 
Saft, Stuart M. 2011a. "Lessons Learned from the Crash: Improving Mezzanine Financing." New York Law Journal, March 14. Available at http://174.143.32.93/ /media/Files/inthenews/2011/20110321_LessonsLearned.ashx.

Saft, Stuart M. 2011b. "Preferred Equity Investor." Commercial Real Estate Workouts, 3rd. ed., $\S 6: 13$. New York: McGraw-Hill.

Spyksma, Sarah V. J. 2011. "Joint Ventures as a Financing Vehicle." Commercial Real Estate

Financing 2012: Getting Back to Business. 2, 105-120.
Steiner, Jeffrey B., and Zachary Samton. 2011. "Intercreditor Dis-Agreements." New York Law Journal, July 20. Available at www.newyorklawjournal.com /PubArticleNY.jsp?id=1202503351990\&Intercreditor_DisAgreements.

\section{ABOUT THE AUTHOR}

Andrew R. Berman is Professor of Law and Director at the Center for Real Estate Studies at the New York Law School. Professor Berman teaches real estate transactions and finance, property, real estate transactional skills, and other advanced real a a partner at Sidley Austin LLP's New York Real Estate Group. Professor Berman was in private practice nearly 15 years. He is an expert on various aspects of real estate law, including real estate finance, sales and purchase contracts, real estate national press and called upon to be an expert witness and consultant on major litigation cases and transactions. He received an AB from Princeton University from the Woodrow Wilson School of Public and International Affairs and holds a JD, cum laude, from New York University School of Law.

\section{ACKNOWLEDGMENTS}

The author thanks his student research assistant, Jeffrey Kahn (NYLS, Class of 2013)

for his invaluable assistance with the preparation and research of this chapter. 